\title{
POSSIBILITIES OF INFLUENCING INDIVIDUAL COMPONENTS OF SELF-ASSESSMENT OF PUPILS' SCHOOL PERFORMANCE BY METACOGNITIVE STRATEGIES
}

\author{
[MOZNOSTI OVPLYVNOVANIA JEDNOTLIVYCH ZLOZIEK \\ SEBAHODNOTENIA SKOLSKEHO VYKONU ZIAKOV \\ METAKOGNITIVNYMI STRATEGIAMI]
}

Juraj Komora - Katarina Vyrostekova

\section{doi: 10.18355/PG.2017.6.2.11}

\begin{abstract}
Success at school often depends not only on the predispositions or experiences of the child, which has acquired under the influence of various external or internal factors, but it also reflects the level of self-knowledge, which is followed by the level of self-confidence. The concept of self-interest influences the attitude of the child to school work, its duties, as well as its expectations of the overall learning outcomes. This naturally implies that one of the priorities in working with a pupil is to develop his self-esteem competences in the sense of an objective assessment of the factors affecting his performance. If the child is able to realistically assess his / her options in relation to the external conditions determining his / her learning activity, this is an extremely important prerequisite for proper adjustment of the processes of self-development. One of the conditions for such a setting is the development of metacognition. Professional literature dealing with the issue currently offers a number of strategies to advance the pupil in this area. The question remains to what extent these strategies can influence the individual components of the self-assessment of the pupil's school performance.
\end{abstract}

\section{Key words}

self-assessment, components of self-assessment, metacognition, metacognitive strategies

\begin{abstract}
Abstrakt
Úspech v škole mnohokrát nezávisí len od predispozícií či skúseností diet'at'a, ktoré nadobudlo pôsobením rôznych vonkajších resp. vnútorných faktorov, ale odvíja sa aj od úrovne jeho sebapoznania, z ktorého následne vyplýva úroveň sebadôvery. Predstava o vlastných možnostiach ovplyvňuje postoj diet'at'a ku školskej práci, jeho povinnostiam, ako aj jeho očakávania konečného výsledku učebnej činnosti. Z toho prirodzene vyplýva, že jednou z priorít v práci so žiakom je rozvoj jeho sebahodnotiacich kompetencií, v zmysle objektívneho posúdenia faktorov ovplyvňujúcich jeho výkon. V prípade, že diet’a je schopné reálne posúdit' svoje možnosti vo vzt'ahu k externým podmienkam determinujúcim jeho učebnú činnost', je to mimoriadne dôležitý predpoklad správneho nastavenia procesov sebarozvoja.
\end{abstract}

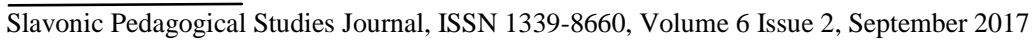


Jednou z podmienok takéhoto nastavenia je aj rozvoj metakognície. Odborná literatúra zaoberajúca sa predmetnou problematikou v súčasnosti ponúka množstvo stratégií zameraných na progres žiaka v tejto oblasti. Otázkou zostáva, do akej miery dokážu tieto stratégie ovplyvňovat' konkrétne zložky sebahodnotenia školského výkonu žiaka.

\section{Kl'účové slová}

sebahodnotenie, zložky sebahodnotenia, metakognícia, metakognitívne stratégie

\section{Úvod}

Príspevok nadväzuje na štúdiu, ktorá bola publikovaná $\mathrm{v}$ tomto periodiku v prvom čísle v roku 2016. V spomínanej štúdii sme sa zaoberali tým, či nami aplikované metakognitívne stratégie učenia, ovplyvňujú úroveň sebahodnotenia školského výkonu žiakov. Našou hlavnou metódou pre získanie potrebných údajov bol experiment. Na základe výskumných zistení sme potvrdili, že existuje rozdiel v sebahodnotení školského výkonu žiakov medzi kontrolnou a experimentálnou skupinou po aplikácii metakognitívnych stratégii učenia, pričom žiaci v experimentálnej skupine dosahovali vyššiu úroveň sebahodnotenia školského výkonu ako žiaci v kontrollnej skupine.

Sebahodnotenie školského výkonu žiakov však tvoria tri zložky sebahodnotenie školskej práce, hodnotenie svojej úspešnosti v triede a hodnotenie svojho strachu zo školy. Preto sme sa v rámci nášho d’alšie skúmania zamerali na to, ktorá zo zložiek sebahodnotenia školského výkonu žiakov stredných škôl bude po aplikácii metakognitívnych stratégii učenia vykazovat' najvyššiu úroveň ovplyvnenia.

\section{Teoretické východiská riešeného problému}

Podla M. Vágnerovej $(2005$, s. 401) primeraná sebadôvera umožňuje žiakovi pracovat' na úrovni zodpovedajúcej jeho schopnostiam. Znížená sebadôvera bráni diet'at'u aby dosiahlo výsledky, ktoré by mohlo dosiahnut' vzhl'adom k svojim schopnostiam a potenciálu. Žiaci so zníženou sebadôverou bývajú často neistí, majú vyšší sklon k úzkostnému reagovaniu, negatívnym očakávaniam a často mávajú obavy zo zlyhania.

Z nášho pohl'adu žiak, ktorý pozná svoje možnosti a schopnosti, vie čo dokáže a v čom má naopak nedostatky, vie si stanovit' primerané ašpirácie zodpovedajúce jeho potenciálu a vie si vybrat' tie najvhodnejšie stratégie učenia, ktoré mu pomôžu dosiahnut' svoj ciel' a dosahovat' v školskej práci úspešné výkony, má mieru sebadôvery na primeranej úrovni. Od úrovne sebadôvery sa odvíja aj úroveň sebahodnotenia.

V. Smékal (2002, s. 353) vníma sebahodnotenie ako jadro jastva, pokial' nim cítime a prežívame stav, že posudzujeme a oceňujeme svoje vlastne ja. Sebahodnotenie má dva póly: spokojnost' a nespokojnost' so sebou. Prežívame ho tiež ako väčšiu alebo menšiu sebadôveru, väčšie alebo menšie sebavedomie. Podl'a R. Kohoutka (2001, s. 169) je sebahodnotenie centrom osobnosti človeka. Je toho názoru, že bez určitej minimálnej úrovne pocitu 
vlastnej hodnoty nemôže človek žit'. Preto si túto úroveň stráži a ak z akéhokol'vek dôvodu klesá, snaží sa o jej vyrovnanie.

J. D. Brown, K. A. Dutton a K. A. Cook (2001, s. 615-631) vymedzujú tri spôsoby, v ktorých je tento pojem najčastejšie užívaný:

1. Globálne sebahodnotenie. Podl'a autorov vyjadruje celkový vzt'ah k sebe, aké pocity máme k svojej vlastnej osobe. Človek s vysokým sebahodnotením má podl'a spomínaných autorov pozitívny vzt'ah k sebe samému. Naproti tomu, ak sa jedná o človeka s nízkym sebahodnotením, tento má $\mathrm{k}$ sebe len mierne pozitívny či ambivalentný vzt'ah. V extrémnom prípade môže človek s nízkym sebahodnotením sám seba až nenávidiet', takýto vzt'ah k sebe však nie je bežný u normálnej populácie, vyskytuje sa len v populácii klinickej. Vnímajú teda sebahodnotenie ako emočný vzt’ah k sebe, zároveň však poukazujú aj na iné chápanie tohto termínu, v ktorom sa uplatňuje najmä kognitívne pojatie. Podl'a tohto globálne sebahodnotenie vyjadruje celkový úsudok človeka o jeho vlastnej hodnote (self-worth).

2. Sebahodnotenie vat'ahujúce sa $k$ pocitom vlastnej hodnoty, ocenenia (feelings of self-worth). V tomto zmysle hovoríme o sebahodnotiacich reakciách na svoje jednanie. Tieto reakcie môžu mat' emocionálny alebo hodnotiaci charakter, napríklad nimi môžu byt' pocity pýchy, potešenia, či naopak zahanbenia zo seba samého.

3. Použitie $v$ zmysle self-evaluation. Posledný prípad používania sa vzt'ahuje $\mathrm{k}$ tomu, ako l'udia ohodnocujú svoje schopnosti, fyzické charakteristiky, či psychické vlastnosti.

Medzi najčastejšie aspekty sebahodnotenia zarad'ujú M. Blatný a A. Plháková (2003, s. 119) nasledujúce aspekty:

- Aspekt pozitivity alebo negativity - patrí medzi najdôležitejšie aspekty sebahodnotenia. Ovplyvňuje výkon, sút’aživost', konformitu, kauzálnu atribúciu. Tento aspekt sa spája s pocitom spokojnosti a duševného zdravia jednotlivca.

- Aspekt nízkeho alebo vysokého sebahodnotenia - v tomto aspekte je venovaná vel'ká pozornost' negatívnym dôsledkom nízkeho alebo vysokého sebahodnotenia. Ukazuje sa, že l’udia s vysokým sebahodnotením majú tendenciu zlyhávat' vo svojich výkonoch. Toto zlyhanie je dôsledkom nadhodnotených názorov na seba, svoje schopnosti, najmä ich preceňovania. Odmena, ktorú potom následne získajú, je vo väčšine prípadov nižšia ako odmena u l'udí s nižším sebahodnotením. Tí si stanovujú ciele adekvátne k svojim schopnostiam a možnostiam.

- Aspekt stability sebahodnotenia - tento aspekt preukazuje, že pre výkon a reakciu na interpersonálnu spätnú väzbu je stabilita sebahodnotenia dôležitejšia ako to, či je sebahodnotenie vysoké alebo nízke. L’udia so stabilným sebahodnotením priaznivejšie reagujú na pozitívnu spätnú väzbu a defenzívnejšie na negatívnu.

Naše sebahodnotenie sa v priebehu nášho života mení. Tak ako jednotlivec prechádza jednotlivými vývinovými obdobiami, tak aj v sebahodnotení

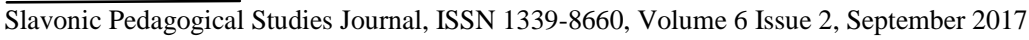


zaznamenávame zmeny, ktoré sa u ludí rovnakého veku prejavujú približne rovnakým spôsobom. Niekedy naše sebahodnotenie $\mathrm{v}$ určitom období klesá a inokedy naopak stúpa. Tieto výkyvy zapríčiňujú zmeny v našom sociálnom prostredí a taktiež vývinové zmeny $\mathrm{v}$ adolescencii alebo $\mathrm{v}$ starobe (Robins, R., W., Trzesniewski, K., H., 2005, s. 158).

V nasledujúcich vývinových obdobiach sa stručne pokúsime zobrazit' priebeh sebahodnotenia od predškolského veku až po obdobie staroby:

- Sebahodnotenie v predškolskom veku - deti majú relatívne vysoké sebahodnotenie, ktoré ale v priebehu detstva postupne klesá. Môže to byt' spôsobené tým, že sa deti v tomto veku nerealisticky pozitívne vnímajú. Toto vnímanie však nie je ešte stabilné a vel'mi závisí od názorov iných ludí, predovšetkým rodičov. Podobne sa vyjadruje aj M. Vágnerová (2000, s. 116), ktorá taktiež zdôrazňuje, že sebahodnotenie dietat’a predškolského veku je stále jednoznačne závislé na názore iných, predovšetkým rodičov vzhl’adom $\mathrm{k}$ ich citovej a rozumovej nezrelosti.

- Sebahodnotenie v mladšom a strednom školskom veku - toto obdobie je príznačné prechodom dietat’a z materskej školy na základnú školu. Výkon dietat'a $v$ škole vo vel'kej miere ovplyvňuje sebahodnotenie diet’ata. Ako uvádza M. Vágnerová (2005, s. 401), v školskom veku je sebahodnotenie $\mathrm{v}$ značnej miere závislé na skutočnom výkone, ktorý sa stáva prostriedkom potvrdenia vlastnej hodnoty. Školáci sú k svojim výsledkom kritickejší ako deti v predškolskom veku. Už im nestačí, aby úlohu splnili, ale chcú úlohu vykonat' správne a očakávajú, že za to budú odmenení. Požiadavky kladené zo strany učitel'ov, rodičov a neskôr aj svojich rovesníkov deti v školskom veku začínajú vnímat' ako určité normy správania a výkonov. Na základe požiadaviek si dokážu vytvorit' normatívnu predstavu o sebe samom, s ktorou sa neskôr aj stotožnia, a usilujú sa predstavu aj reálne splnit'. Môže sa však stat' to, že diet'at'u sa nepodarí jeho predstavu o sebe samom naplnit' a tak môže sebadôvera diet'at'a klesat'.

- Sebahodnotenie v období puberty a adolescencie - v puberte dochádza k poklesu sebahodnotenia. Predpokladáme, že je to spôsobené zvýšeným záujmom o svoj vzhl'ad a zovňajšok. V tomto veku sa pubescenti vel'mi dôkladne sledujú, pozorujú, porovnávajú s druhými a posudzujú sa predovšetkým podl'a toho, ako ich vnímajú. Ako uvádzajú J. Langmeier a D. Krejčířová (2006) dospievajúci začínajú dôkladne skúmat' svoj zovňajšok a v súlade $\mathrm{s}$ tým sa o svoj vzhl'ad začínajú starat'. Jednotlivci s nízkym sebavedomím však často na sebe nachádzajú nedostatky, čo sa následne odzrkadlí na ich celkovom sebahodnotení. Koncom tohto obdobia, vstupom do adolescencie, sa však sebahodnotenie opiera o komplexnejšiu analýzu motívov. Predmetom hodnotenia sa stávajú vlastné kompetencie a na nich závislé výsledky. Pre sebahodnotenie sú najdôležitejšie výkony $\mathrm{v}$ oblasti, ktorá je pre adolescenta nejakým spôsobom významná (Vágnerová, M., 2000). Aj J. Výrost a I. Slaměník (2008) potvrdzujú, že ak charakteristiky, ktoré človek považuje za dôležité, hodnotí pozitívne a stabilne, prispieva tak $\mathrm{k}$ vysokému sebahodnoteniu. 
- Dospelost' - úroveň sebahodnotenia v tomto období postupne narastá a svoj vrchol dosahuje okolo 60-teho roku života, kedy väčšina l'udí je na vrchole svojich úspechov, znalostí, kontroly seba aj okolia. Niekol'ko štúdií sebahodnotenia v starobe naznačujú, že okolo 70-teho roku života začne sebahodnotenie klesat'. Tento pokles sa pripisuje dramatickým zmenám, ktoré staroba prináša. Ide napríklad o zmeny v sociálnej roli (odchod do dôchodku), zmeny vo vzt'ahoch (strata manželky alebo manžela), vo fyzických funkciách (zdravotné problémy), ako aj pokles sociálnoekonomického postavenia (Robins, R., W., Trzesniewski, K., H., 2005, s. 159-160).

Každé obdobie má teda vo vzt’ahu k sebahodnoteniu množstvo charakteristických aspektov. Nás ale v našom výskume, z pochopitel'ných dôvodov, najviac zaujímalo obdobie, ktoré sa vo vzt’ahu k sebahodnoteniu vyznačuje značnou nestabilitou - obdobie puberty a adolescencie. Vzájomný vzt’ah sebahodnotenia a metakognície preukazuje tzv. triadická teória autoregulácie od B. Zimmermana (1990, s.6-7), ktorá pozostáva z troch subsystémov autoregulácie, pričom jeden z nich, autoregulácia správania, je založený práve na sebahodnotení žiaka. Žiak pri sebahodnotení hodnotí svoje všeobecné aj špeciálne učebné schopnosti, svoju výkonnost' v jednotlivých predmetoch, svoje postavenie v školskej práci v porovnaní s rovesníkmi, svoju úspešnost' v triede, ale aj strach zo školy, čo tvorí základ sebahodnotenia školského výkonu žiaka.

Výskumný problém

Problematike metakognície sme sa podrobnejšie venovali v už spomínanej predchádzajúcej štúdii (pozri vyššie), preto sme jej v teoretických východiskách nevenovali pozornost'. Skôr sme sa zamerali na samotné sebahodnotenie žiaka a jeho rôzne aspekty. Aj preto sme si v rámci nášho skúmania okrem hlavnej hypotézy, stanovili aj niekol'ko výskumných otázok. Jednou z nich bola otázka: „Ktorá zo zložiek sebahodnotenia školského výkonu žiakov stredných škôl bude po aplikácii metakognitívnych stratégii učenia vykazovat' najvyššiu úroven̆ ovplyvnenia?“.

\section{Metodológia výskumu}

Výber vzorky: Výskumný súbor tvorilo spolu 105 žiakov SSOŠ. Z toho experimentálnu skupinu nám tvorilo 53 žiakov a kontrolnú 52 žiakov SSOŠ, pričom bol uplatnený zámerný výber.

Metódy skúmania: Z uvedeného vyplýva, že jednou z metód pri získavaní potrebných údajov $\mathrm{v}$ rámci nášho skúmania bol experiment. Jednalo sa o prirodzený experiment, pričom vexperimentálnej skupine sme manipulovali s nezávislou premennou (metakognitívnymi stratégiami učenia). Experiment dopĺn̆alo dlhodobé pozorovanie.

$\mathrm{Na}$ zist'ovanie úrovne sebahodnotenia sme použili dotazník sebahodnotenia školskej úrovne a vzt'ahu ku škole, ktorý ponúka komparáciu sebahodnotenia žiaka a hodnotenia žiaka rodičmi alebo učitel'om. Bol vypracovaný na základe už známych metód sebahodnotenia diet’at'a (SPAS - dotazník 
sebapojatia školskej úspešnosti diet’at’a). Je možné ho použit' individuálne ale aj skupinovo a obsahuje 15 položiek, ktoré boli na základe faktorovej analýzy rozdelené na tri subškály (Vágnerová, M., 2005, s. 411-414) :

- Sebahodnotenie školskej práce a miera jej zvládania - napr. položka č. 3. „Unavuje ma, ked' musím nad úlohou vel'mi rozmýšlat."

- Sebahodnotenie relatívnej úspešnosti v triede v porovnaní s ostatnými det’mi - napr. položka č. 9. „Väčšina mojich spolužiakov sa v triede učí lepšie ako ja."

- Strach zo školy - napr. položka č. 14. „Ústne skúšanie pred celou triedou ma znervóž̌uje."

Údaje sme spracovali štatistickým programom SPSS (Statistical Package for Social Sciences), v ktorom sme použili konkrétne tieto metódy:

- Koeficient šikmosti (Skewness) a Koeficient strmosti (Kurtosis) štatistické ukazovatele tvaru distribúcie, ktoré nám na základe koeficientov (menšie alebo väčšie ako 1) určujú, či empirické údaje dovol'ujú použit' pri komparácii parametrický test. Nakol'ko distribúcie nami skúmaných premenných $\mathrm{v}$ oboch podsúboroch boli jednovrcholové, koeficienty šikmosti a strmosti boli menšie ako 1 a premenné mali približne normálne rozloženie, použivali sme na štatistické spracovanie výskumných údajov (komparáciou) parametrické testy.

- Studentov t-test pre dva nezávislé výbery (Independent Samples T Test), týmto testom sme zist'ovali štatistickú hladinu významnosti rozdielu v úrovni sebahodnotenia školského výkonu žiakov medzi kontrolnou a experimentálnou skupinou pred aj po aplikácii metakognitívnych stratégii učenia.

\section{Analýza získaných údajov}

$\mathrm{Na}$ výskumnú otázku sme hl’adali odpoved' štatistickým spracovaním získaných údajov vo všetkých troch zložkách prostredníctvom komparácie dvoch kvantitatívnych premenných (1. sebahodnotenie školskej práce pred aplikáciou vs. sebahodnotenie školskej práce po aplikácii metakognitívnych stratégii učenia, 2. úspešnost' $v$ triede pred aplikáciou vs. úspešnost' v triede po aplikácii stratégii, 3 . strach zo školy pred aplikáciou vs. strach zo školy po aplikácii metakognitívnych stratéfii učenia) v jednom súbore (experimentálna skupina žiakov). Nakol'ko podmienka normalita bola splnená a koeficient strmosti a šikmosti bol menší ako 1, distribúcia bola jednovrcholová, sme si ako testovacie kritérium zvolili Stutentov t-test pre dva závislé výbery. Každú zložku sebahodnotenia školského výkonu žiakov sme hodnotili samostatne.

Z tabul'ky 1. je viditel'né, že štatistickú hladinu významnosti rozdielu v dosiahnutej úrovni jednotlivých zložiek sebahodnotenia školského výkonu žiakov pred a po aplikácii metakognitívnych stratégii učenia sme zaznamenali v zložke sebahodnotenie školskej práce. Pričom hodnota Studentovho t-testu pri 52 stupňoch vol'nosti je $-2,846$ a dosiahnutá signifikancia má hodnotu menšiu ako $0,05\left(\mathrm{t}_{(52)}=-2,846 ; \quad \mathrm{p}<0,05\right)$. Úspešnost' $v$ triede a strach zo školy nedosahovali u žiakov SSOŠ signifikantné rozdiely $\mathrm{v}$ dosiahnutej úrovni pred a po aplikácii 
metakognitívnych stratégii učenia. Na základe interpratácie môžeme usúdit', že najvyššiu úroveň ovplyvnenia vykazuje zložka sebahodnotenie školskej práce, ako druhá v poradí je úspešnost' v triede a najmenej ovplyvnenou zložkou sebahodnotenie školského výkonu žiakov je zložka hodnotenia vlastného strachu zo školy. Hodnotenie strachu zo školy však dosahovalo najvyššiu úroveň v sebahodnotení pred aplikáciou metakognitívnych stratégii učenia a aj po ich aplikácii. Nebola však stratégiami ovplyvnená až natol'ko, ako sebahodnotenie školskej práce, ktoré dosahovalo najnižšiu úroveň pred aplikáciou metakognitívnych stratégii učenia a po ich aplikácii sa umiestnila na druhej pozícii v úrovni sebahodnotenia.

\begin{tabular}{|c|c|c|c|c|c|c|}
\hline \multicolumn{7}{|c|}{ Vplyv MSU na jednotlivé zložky sebahodnotenia školského výkonu žiakov } \\
\hline Zložka & Stav & Početnost' & AM & SD & $t$ & Sig. (dvojstranná) \\
\hline \multirow{2}{*}{$\begin{array}{l}\text { Sebahodnotenie } \\
\text { školskej práce }\end{array}$} & Pred apl. & 53 & 4,3585 & 1,7769 & \multirow{2}{*}{$-2,846$} & \multirow{2}{*}{0,006} \\
\hline & Po apl. & 53 & 5,5283 & 2,2413 & & \\
\hline \multirow{2}{*}{$\begin{array}{l}\text { Uspešnost } \\
\text { v triede }\end{array}$} & Pred apl. & 53 & 4,4717 & 2,0995 & \multirow{2}{*}{$-1,18$} & \multirow{2}{*}{0,243} \\
\hline & Po apl. & 53 & 4,9811 & 2,2828 & & \\
\hline \multirow{2}{*}{$\begin{array}{c}\text { Strach zo } \\
\text { Školy }\end{array}$} & Pred apl. & 53 & 5,7547 & 2,3114 & \multirow{2}{*}{$-1,013$} & \multirow{2}{*}{0,316} \\
\hline & Po apl. & 53 & 6,2642 & 2,3871 & & \\
\hline
\end{tabular}

$\mathbf{M S U}=$ metakognitívne stratégie učenia, $\mathbf{A M}=$ aritmetický priemer, $\mathbf{S D}=$ štandardná odchýlka, $\mathbf{t}=$ testovacia hladina, Sig. = hodnota dosiahnutej dvojstrannej signifikancie/významnosti $p<0.05$

Tabul'ka 1. Vplyv metakognitívnych stratégii učenia na jednotlivé zložky sebahodnotenia školského výkonu žiakov SSOŠ pred a po ich aplikácii MSU

Doposial' interpretované údaje potvrdzuje aj tabul'ka 2. (graf 1.), ktorá vyjadruje nakol'ko boli jednotlivé zložky sebahodnotenia školského výkonu žiakov ovplyvnené. $\mathrm{Na}$ základe počtu žiakov dosahujúcich danú úroveň zložky sebahodnotenia školského výkonu žiakov SSOŠ pred aplikáciou metakognitívnych stratégii učenia a po ich aplikácii, vyjadrujeme percentuálne zvýšenie prípadne pokles úrovne v jednotlivých zložkách.

\begin{tabular}{|c|c|c|c|}
\hline \multicolumn{4}{|c|}{$\begin{array}{l}\text { Percentuálne vyjadrenie zvýšenia alebo poklesu úrovne } \\
\text { jednotlivých zložiek sšv žiakov pred a po aplikácii MSU }\end{array}$} \\
\hline Zložka & Stav & $\begin{array}{l}\text { Počet žiakov } \\
\text { v \% }\end{array}$ & $\begin{array}{c}\text { Zvýšenie alebo pokles } \\
\text { úrovne v \% }\end{array}$ \\
\hline $\begin{array}{l}\text { Sebahodnotenie } \\
\text { skolskej práce }\end{array}$ & \begin{tabular}{|l|} 
Pred apl. \\
Po apl.
\end{tabular} & $\begin{array}{c}41,51 \\
71,7\end{array}$ & 30,19 \\
\hline $\begin{array}{l}\text { Úspešnost' } \\
\text { v triede }\end{array}$ & $\begin{array}{l}\text { Pred apl. } \\
\text { Po apl. }\end{array}$ & $\begin{array}{l}58,49 \\
64,15\end{array}$ & 5,66 \\
\hline $\begin{array}{l}\text { Strach zo } \\
\quad \text { školy }\end{array}$ & \begin{tabular}{|l|} 
Pred apl. \\
Po apl.
\end{tabular} & $\begin{array}{l}73,58 \\
73,58\end{array}$ & 0 \\
\hline
\end{tabular}

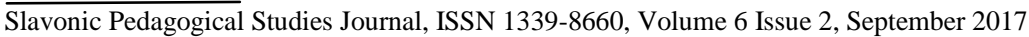


Tabul'ka 2. Percentuálne vyjadrenie zvýšenia alebo poklesu úrovne jednotlivých zložiek sebahodnotenie školského výkonu žiakov SSOŠ po aplikácii MSU

Najvyšší percentuálny nárast sme zaznamenali v zložke sebahodnotenie školskej práce, pričom 30,19\% žiakov dosahovalo hodnoty vyššej úrovne po aplikácii metakognitívnych stratégii učenia. V zložke sebahodnotenia úspešnosti v triede 5,66\% žiakov dosahovalo hodnoty vyššej úrovne po aplikácii metakognitívnych stratégii a v tretej zložke sebahodnotenia (strach zo školy) sme nezaznamenali žiadnu zmenu.

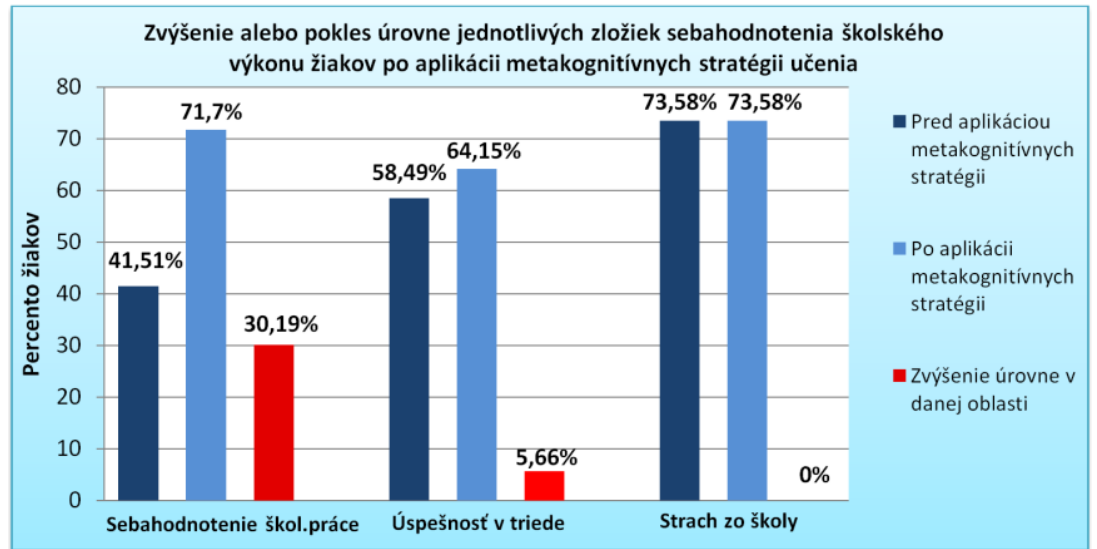

Graf 1. Percentuálne vyjadrenie zvýšenia alebo poklesu úrovne jednotlivých zložiek sebahodnotenie školského výkonu žiakov SSOŠ po aplikácii MSU v grafickej podobe

Na záver štatistickej deskripcie a inferencie môžeme konštatovat', že najvyššiu úroveň ovplyvnenia metakognitívnymi stratégiami učenia u žiakov SSOŠ sme zaznamenali v zložke sebahodnotenie školskej práce. Konkrétne $30,19 \%$ žiakov si zvýšilo svoju úroveň sebahodnotenia školskej práce po aplikácii metakognitívnych stratégii učenia.

\section{Bibliographic references}

BABULICOVA, Z. 2013. Uroven kognicie a moznosti jej rozvijania. Rozvoj (meta)kognitivnych funkcii pri praci s chybou. In Duchovicova, J. - Skoda, J. 2013. Psychodidakticke pojeti kulikuralniho a mediacneho kontextu edukace. Usti nad Labem: UJEP, 290 s. ISBN 9788074146589.

BLATNY, M. - PLHAKOVA, A. 2003. Temperament, Iteligence, Sebepojeti : Nove pohledy na tradicni temata psychologickeho vyzkumu. Brno: Psychologicky ustav Akademie ved, 150 s. ISBN 8086620050.

BROWN, J. D. - DUTTON, K. A. - COOK, K. A. 2001. From the top down: Self-esteem and Self-evaluation. In Cognition and Emotion, vol. 15, n. 5, pp. 615-631. 
https://iths.pure.elsevier.com/en/publications/from-the-top-down-self-esteemand-self-evaluation

DUCHOVICOVA, J.2013. Psychodidaktika v kontextoch sprostredkovaneho a zmysluplneho ucenia. In Duchovicova, J. - Skoda, J. 2013. Psychodidakticke pojeti kulikuralniho a mediacneho kontextu edukace. Usti nad Labem: UJEP, 290 s. ISBN 9788074146589.

FLAVELL, J. H. 1979. Metakognition and Cognitive Monitoring. A New Area of Cognitive Development Inquiry. In American Psychologist, vol. 34, n. 8, pp. $906-911$.

HACKER, D. J. - DUNLOSKY, J. - GRAESSER, A. C. 2009. Handbook of Metacognition in Education. New York: Rotledge, 449 pp. ISBN 0805863532.

HNILICA, K. 1992. Kognitivni a metakognitivni strategie autoregulovaneho uceni. In Pedagogika, roc. XLII, c. 4, s. 477-485 ISSN 0031-3815.

KOHOUTEK, R. 2001. Poznavani a utvareni osobnosti. Prvni vydani. Brno: CERM Brno, 274 s. ISBN 8072042009.

LANGMEIER, J. - KREJCIROVA, D. 2006. Vyvojova psychologie. Praha: GRADA, 368 s. ISBN 9788024712840.

ROBINS, R., W. - TRZESNIEWSKI, K., H., 2005. Self-esteem Development Across the Lifespan. In Current Directions In Psychological Science, vol. 14, n. 3, pp. 158. Dostupne na internete: http://www.psy.miami.edu/faculty/dmessinger/c_c/rsrcs/rdgs/emot/robins_trz .selfesteemdevel_curidr2005.pdf

SIMONS, P. R. J. 1994. Metacognitive Strategies - Teaching and Testing for. In International Encyclopedia of Education. Oxford, Elsevier Science, pp. 3788-3792. [on-line] [2010/19/12] Dostupne na internete: http://igiturarchive.library.uu.nl/ivlos/2005-0622- 190116/5831.pdf

SMEKAL, V. 2002. Pozvani do psychologie osobnosti. Clovek v zrcadle vedomi a jednani. Brno: Barrister\&Principal, 2002. 517 s. ISBN 8085947803.

SKODA, J. - DOULIK, P. 2011. Psychodidaktika. Metody efektivneho a smysluplneho uceni a vyucovani. Praha: Grada, 206 s. ISBN 9788024733418.

VAGNEROVA, M. 2000. Vyvojova psychologie: detstvi, dospelost, stari. 1. vyd. Praha: Portal, 528 s. ISBN 8071783080.

VAGNEROVA, M. 2001. Kognitivna a socialna psychologie skolniho zaka. Praha: Karolinum, 304 s. ISBN 8024601818.

VAGNEROVA, M. 2005. Vyvojova psychologie I. Detstvi a dospivani. Praha: Karolinum, 467 s. ISBN 8024609568.

VYROSTEKOVA, K. 2012. Modifikacia vyucovacich strategii zameranych na ucebnu cinnost ziakov. Dizertacna praca (obhajena august 2012). Nitra: PF UKF v Nitre, $103 \mathrm{~s}$.

VYROST, J. - SLAMENIK, I. 2008. Socialni psychologie. Praha: GRADA, 416 s. ISBN 9788024714288.

ZIMMERMAN, B. J. 1998. Developing Self-Fulfiling Cycles of Academic Reagulation: An Analysis of Exemplary Instructional Models. In

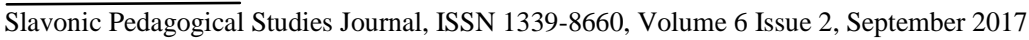


ZIMMERMAN, B. J. - SCHUNK, D. H. Self-Regulated Learning - From Teaching to Self-Reflective Practice. New York: Guilford Press, pp. 1-19, ISBN 1572303069.

Doc. PaedDr. Juraj Komora, PhD.

PaedDr. Katarína Vyrosteková, PhD.

Department of Education

Faculty of Education

Constantine the Philosopher University

Drážovská cesta 4, 94974 Nitra

Slovakia

jkomora@ukf.sk

kvyrostekova@ukf.sk 